\title{
Quantitative and qualitative problems of short film production in cinema education in Turkey
}

\author{
Mehmet Emrah Erkanı 1a \\ ${ }^{1}$ Phd,Balmumcu Dere Sk.13/6,Istanbul 34379, Turkey
}

\begin{abstract}
Although Turkish cinema has completed its 100 years, short film could not find the place it deserves in the institutions and in the sector. There are problems in terms of the narrative and technical characteristics of short films beside presentation, marketing and international festival attendance issues. Low budgets, course schedules and structures of the cinema departments and short films and the sector's ignorance of the importance of short film are the obstacles to the development of short films in Turkey. Increasing the government support, strengthening the cooperation between the sector and the university, improving the festivals' screening conditions, reforming the arrangements to increase the sponsorship incentives, solving the equipment problems of the institutions will positively affect the productivity of Turkish cinema.
\end{abstract}

Keywords. Turkey; short film; film education; university.

\section{Introduction}

Short films are movies lasting less than thirty minutes and that are produced in documentary, fictional, animation and experimental styles. It also is a congruent instrument for many explicandums such as underground, surrealistic and experimental that probably will not be able to find their ways into the main stream cinema. There is no point in taking the main stream cinema produced due to commercial concerns on one hand and short films on the other to create a conflict by discussing which one has a more artistic taste or comparing them to each other. Both sides can be said to be amusing or artistic conditionally. And each side is in need of investors, distributors, motion picture theatres, festivals; namely an established system. As a means of artistic expression, the ability of short films to give constructive criticisms a seat in an easier way stems from its independence from the cohesiveness of these systems even if a tiny bit. The only way to maintain that independence is to have an unbiased, uncensored and libertarian approach from the government towards the art.

\footnotetext{
${ }^{a}$ Corresponding author: emrah.erkani@gmail.com
} 


\section{Short film and cinema in Turkey}

There are some vexed issues in Turkey that should be solved in order for cinema to be able to speak from the local to the universal and to talk about a national cinema. Unfortunately cinema in Turkey couldn't evolve from being solely for entertainment into an art. This approach of community towards the cinema, government's perception or art and stylistic problems of the commercial cinema are the reasons why the Turkish cinema painted itself into a corner today. As the public doesn't see the cinema in an artistic way, they naturally have no interest or demand on the short films. Under these circumstances sector also doesn't have an eye on a production without financial return and no one invests.

Turkish cinema has celebrated its 100th year in 2014. Even though this familiarity of a century with the cinema, the cinema education could only start in the year of 1976 academically. It's not easy to overcome the negative effects of the delayed start of academic cinema education after a long period where films were gropely produced. [2] Whether in government universities or in foundation universities, the financial possibility of the cinema departments is not enough for the applied cinema education.

\section{Quantitative and qualitative problems of cinema education and short film production}

Particularly with the swift increase in the numbers of foundation universities, the problem of a competent cinema education has revealed itself more significantly.

Ending the central system in student admission to the relevant institutions and turning it into a genuine and elaborate structure is one of the steps that should be taken initially. Instead of crashing the students with productions in cinema or other branches of art between the wheels of the central system, these students should take a special talent exam held by the institutions themselves and where the candidates can use their creativity and accumulation or present their portfolios. [3]

It is not really possible to raise competent cinema people because of the lack of infrastructure in the cinema education where applied education is of great importance. Short film studies the students create through their own means and in low standards technically don't provide a satisfying result in terms of content and style. It's needless to say that the students are last ones to be held responsible for that. Students pay the price of insufficient education emerged in the cinema education requiring high costs. To have a general view, I have conducted a basic satisfaction survey with the people still continuing their education or graduated and I have seen that many of them believe that the academic education they received is not enough to get a job in the sector. Another trouble they have is the technical inadequacy.

It should also be calculated statistically whether the cinema sector in Turkey needs those personnel being raised in so many departments providing cinema education. [1]

Rooted institutions such as Famu, Prague Film School, and La Femis have both financial resources and serious government supports. We can see that these institutions are in an important collaboration with the sector and this includes the employment of the graduates in the sector. However, people raised in Turkey are highly disconnected from the sector. Both sides need to support the collaboration between each other. Good intentions such as inviting professionals from the sector to the workshops and sessions in the university are far from enough. Training opportunities must be created as a part of the education for the students to earn experience in the areas they want to specialise.

Government is responsible for executing the required incentives in this sense. Some quotas can be implemented at some point for TV channels', advertisement agencies' and production companies' contributing to the school and short film production. 
For instance, the announced budget of La Fémis on the internet is 10.7 million Euros. $76 \%$ of this amount is provided by CNC (Centre National du Cinema et de l'image anime), $17 \%$ is acquired by school's own resources and the other $7 \%$ consists of the grants the companies in the cinema sector pay which can be named as "traineeship tax". More info may be found at the official website of La Fémis (http://www.femis.fr).

The main institution in Turkey supporting the cinema is the Cinema General Directorate. Other than this institution, it is possible to say that there are some really small amounts of funds created by civil initiatives.

If we take the numbers given in the website of the Cinema General Directorate (The official website of the Cinema General Directorate http://www.sinema.gov.tr), even total support given to the feature-length cinema films were 66489646 TRY (approximately 23, 3 Million Euro) between 2005-2013. It is not possible to gather any data via internet websites regarding whether the cinema departments have a satisfying budget of their own that can be announced.

As the Cinema General Directorate have undertaken turning the cinema into an industry in Turkey as a duty, they should provide more support to the independent cinema productions, particularly the short films. In the year of 2015, a financial support amounting 7000-20000 TRY was granted to the short film projects but this amount is far from being sufficient if one considers even only the rental fees for the equipment, thus it is highly a low amount to create a short film of good quality. Also putting incentives such as tax discounts to attract investors into effect so that the producers and the directors can find financial support for their projects is one of the solutions along with the direct grants from the government. UniFrance in France provides grants to the short films. Some regulations were made so that the local film productions and motion picture theatres would be supported. A similar regulation is in force in Italy. Funds and cinema channels created by local governments support short film projects.

And even when a short film director realizes one of his projects, then the problem of making one's presence felt in the foreign festivals emerges. Speaking of an adequate promotion and marketing network is out of question. And it is also almost impossible to get financial support from the regarding government institutions in case of participating in an international festival.

The problem about introducing the film to the audience should also be evaluated in this frame. Many short film festivals are held in Turkey. Nevertheless, this quantitative increase doesn't carry a quantitative satisfaction with it. It's no surprise to encounter poor-quality sound and visual systems in these festivals created with tight budgets often. And it cannot be said that the short film screening organized within the body of certain international festivals is enough.

The image that festivals are only useful to watch free short films has to be changed now or from now on. Organizations, where markets were created to introduce new projects to the common producers, a wider coverage is given to the project presentations, and where there are rooms that can be used to watch non-contestant films, should be held. TV channels also should be led to be more active in the process of introducing the film to the audience.

Short film should be saved from the false perception that it is just a step in the way to the feature-length or it's just an education tool for students. It is true that directors starting from the short films shot feature-length films afterwards. Nonetheless, there are also directors in many developed countries shooting short films professionally and earning their keep from it. It should also be noted that even the feature-length directors are making short film production providing them with more freely expression and criticism opportunities at times. 


\section{Conclusion}

A change in the mentality is obligatory. Short films are one of the artistic production areas that should be paid a great deal of attention in the culture plan of the government. Just because it doesn't possess financial return, if such a powerful branch of art that bares the power to question, criticise the structure of the community and thereby leading the community the short film itself stems from to evolving into a more prolific and liveable state is left forlorn, it will pose a serious problem for the future of the national cinema. Along with improving the structural and physical conditions of the cinema education institutions, increasing the budget of the institutions that supports cinema; making regulations to let them have an independent, unbiased and consistent structure is of great importance as well.

\section{References}

1. Adanır, O. Kültür, politika ve sinema. İstanbul: +1 Kitap, (2006).

2. Adanır, O. Sinemada anlam ve anlatım, İstanbul: Say Yayınları, (2012).

3. Russell, B. Eğitim üzerine, İstanbul:Say Yayınları, (2001). 